\title{
MÁRIA TERÉZIA PÁTENSEI A HADIROKKANT ELLÁTÁSRÓL - 1. RÉSZ
}

\author{
Szerzők: \\ Mihók Sándor (Dr. Jur.) \\ nyugalmazott jogtanácsos \\ Fejes Zsolt (PhD) \\ Magyar Honvédség Egészségügyi Központ \\ Helyes Marcell \\ Karl-Franzens Universitat (Ausztria) \\ Első szerző e-mail címe: \\ sakinew@hotmail.com
}

\section{Lektorok:}

Kóródi Gyula (Prof. Dr.)

Nemzeti Közszolgálati Egyetem

Rikk János (PhD)

Kodolányi János Egyetem

...és további két anonim lektor

\begin{abstract}
Absztrakt
Jelen tanulmányunkban - egy cikksorozat első részeként - Mária Terézia kevésbé ismert 1750ben kiadott, hadirokkant ellátásról szóló rendeletét mutatjuk be. A pátensben az uralkodó az osztrák örökösödési háborúkban (1740-1748) részt vett nemzetek és a súlyos harcok során „a tagjaikat, egészségüket és épségüket feláldozó katonák” iránt érzett háláját kívánta kifejezni. A rendelet áttekintését követően kitérünk a rokkantkérdés megoldásának egy korabeli „sikeres” intézményére, a hadirokkantak telepítésére is. Cikksorozatunk második részében a Pesti Invalidus Ház történetét tekintjük át 1750-től az 1783-ban történt megszűnésig, különös tekintettel a rokkantrendelet 1772-ben történt revíziójára. Továbbá betekintést nyújtunk a rokkant katonák rendhagyó életpályájába, az „újrahasznosított” hadirokkantak kalandos hétköznapjaiba.
\end{abstract}

Kulcsszavak: hadigondozás, hadirokkant otthon, rokkantellátási rendelet

Diszciplínák: történelem, orvostudomány, hadtudomány

\begin{abstract}
MARIA THERESLA'S PATENTS ON THE PROVISION OF BENEFITS TO DISABLED VETERANS - 1ST PART

In this essay - which is the first part in a series of articles - we will present Maria Theresia's lesser-known 1750 patent (decree) on the provision of benefits to disabled veterans. With this patent, the Queen intended to show her gratitude to the nations and soldiers who fought in the War of the Austrian Succession (1740-1748), and especially to those „soldiers who sacrificed
\end{abstract}


their body parts, health and wholesomeness" in the heavy fights. After reviewing the decree, we will examine a "successful" institution of the time that was meant to resolve the issue of the disabled: the settlement programmes for disabled veterans. In the next part of the series, we will review the history of the Invalids' Home in Pest from the year 1751 to 1783, when it was closed. Special emphasis will be placed on the revision of the Disability Decree, which took place in 1772. Furthermore, we will provide readers with an insight into the unorthodox careers of disabled soldiers, and into the eventful daily life of the "recycled" disabled veterans.

Keywords: military nursing, home for disabled veterans, decree on the provision of benefits to the disabled

Disciplines: history, medicine, military science

Mihók Sánodr, Fejes Zsolt és Helyes Marcell (2020): Mária Terézia pátensei a hadirokkant ellátásról - 1. rész. Lélektan és hadviselés - interdiszciplináris folyóirat, II. évf. 2020/2. szám. 73-87. doi: 10.35404/LH.2020.2.73

\section{A hadirokkantak telepítése}

Európában az intézményes és szélesebb alapon szervezett hadigondozás az első világháború előtt szinte teljesen ismeretlen volt. Az ókori római és hellenisztikus emlékek azonban igazolják, hogy a hadisérültek „fáradozásaikért” már szerény juttatásban részesültek.

Kultúrtörténeti érdekesség, hogy az ezópusi mesékben is találhatók oktató utalások a rokkantak megbecsülésével kapcsolatban. Macedóniai Nagy Sándor a háború veteránjait és rokkantjait példaképül állította a fiatal katonái elé, de pénz és földjuttatásokkal is igyekezett a kiszolgált harcosok hátralévő nyugodt éveit biztosítani. Nagy Sándor megparancsolta, hogy a háborúban elesett katonák árvái megkapják apjuk ki nem fizetett járandóságait. Hérodotosz arról írt, hogy a veteránok részére Egyiptomban létesítettek telepeket, és a rokkant katonákat a templomok közelében helyezték el, telepítették le (Théba - v.ö.: Takáts, 2007, Mihók, 2019).

A háborús rokkantak tiszteletére - a hálás polgárok kezdeményezésére - négy napot jelöltek ki az Augusztus császár idején használatos római naptárban. Az erkölcsi megbecsülésen túl a megrokkant katonák az ókori Rómában részesedtek a hadizsákmányból, ezen kívül földet, jutalmat és még egyéb kedvezményeket is kaptak.

A középkor keresztes háborúi alatt is sok vitéz vesztette el testi épségét, akiknek ugyancsak kellő tisztelet járt, hiszen még a templomokban is külön padsorokat tar-tottak fenn számukra (Melly, 1932). 
Az állami ellátás szinte egyedülálló intézménye volt a francia IX. (Szent) Lajos király által az 1260-as évek végén vak keresztesek számára alapított 300 férőhelyes párizsi „Hôpital des Quinze-Vingt” kórház (Gentili, 2017).

A folyamatos háborúskodásban élő Velencei Köztársaság 1318-ban a hadvise-lésben megrokkant tengerészeinek nyitott - hosszú távú elhelyezésre alkalmas - otthont (Gabriel, 2013).

III. Henrik király az árvák és a város szegényei részére Párizsban szerény otthont létesített, melynek az is feladata volt, hogy oltalmába vegye a háborús rokkantakat. IV. Henrik támogatásával 1576-ban létrehozták az ún. „Maison de la Charité chrétienne” rokkantházat. Később ugyan bezárták az otthont, de a nőtlen rokkantakat kolostorokban helyezték el, a családosok részére pedig szerény juttatást is megállapítottak (Héjja, 1936).

A 17. század elején azonban uralkodóvá vált az a szemlélet, mely szerint csak azok részére van szükség állandó katonakórházra, akik rokkanttá válnak és állandó ápolásra, vagy kezelésre szorulnak. A nézet gyökerei az 1630. évi itáliai francia háborúig nyúlnak vissza. A háború után ugyanis Richelieu az úton-útfélen kéregető és erőszakoskodó rokkantak „kórházba” - a „Hôpital de la Pitie”-be - történő elhelyezését rendelte el (Takáts, 1975). Így kerültek a bíboros utasítására zár alá a „Hôpital de la Pitie”-ben a súlyos rok-kantak, míg a többieket vidéki várakba irányították kisebb szolgálatra, vagyis Párizsból végleg kitiltották őket.

Mindenképpen említést érdemel, hogy XIII. Lajos 1634-ben kórházat létesített a fogya- tékkal élő katonáknak. A „Hôpital Bicêtre” azonban az uralkodó halála után bezárta kapuit és a rokkant katonák sorsa ismét olyanná vált, mint amilyen viszontagságos volt IV. Henrik uralkodását megelőzően (Niox, 1909).

A Napkirály, XIV. Lajos 1670-ben elhatározta, hogy rokkant katonáinak pa-lotát emeltet. 1679-ben átadták a 6000 fő befogadására alkalmas „Hôtel Royal des Invalides"-t, az Invalidusok Palotáját, amely a hadügyminiszter közvetlen alárendeltségébe tartozott. Az Invalidusok Palotája nem egyszerúen csak a rokkant katonák otthona volt, hanem egy laktanya, kórház és manufaktúrák tucatjai által alkotott zárt városrész is. Jelentőségét alátámasztja az a tény, hogy az európai államok az Invalidusok Palotája építészeti és szervezeti rendszerét (katonai igazgatás, egészségügy és hitélet) vették alapul - de leginkább másolták - a saját katonai rokkantházaik létesítésekor.

Az angliai Chelsea-ben 1680-ban a szárazföldi, Greenwichben pedig a tengeri haderő rokkantjainak szerveztek gondozóintézetet. Oroszországban a cár 1682-ben több monostort utasított rokkant katonák befo-gadására (Mihók, 2018).

Ausztriában a rokkantak gondozására épült a bécsi Allgemeine Krankenhaus, a töröktől felszabadult és lassú fejlődésnek induló Pest elsô nagyszabású épülete pedig az esztergomi prímás kezdeményezésére és anyagi támogatásával épített, de végső formájában „nagyívü” uralkodói szándékokat megvalósító Pesti Invalidus Ház volt. Az épület politikai mondanivalóját a hatalmas méret, az abszolút kiterjedés mint a hatalom, a központi erő végtelen erejének a kifejezése adja meg (1. 
ábra). III. Károly alapvető célja ezzel kizárólag az volt, hogy a párizsi Invalidusok Palotáját minden tekintetben felülmúlja (Kelényi, 2005).

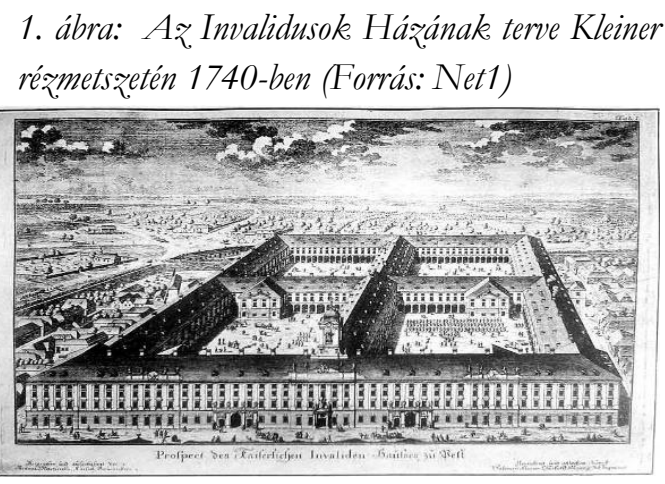

A francia mintára épült Pesti Invalidus Ház belső szabályzattal, saját rendfenntartókkal és haditörvényszékkel rendelkező katonai intézmény volt. Jogilag területen-kívüliséget élvezett és nem tartozott Pest város joghatósága alá. A 18. század közepén „az aggostyánok pesti palotájában” 2500 ember élt a közel négy hektáros területen, és túlzás nélkül állít-hatjuk, hogy város volt a városban. Az intézmény vezetője általában egy magas rangú tiszt volt, az ott élő invalidusok mindennapi életét katonai rendtartások szabályozták.

Valójában itt minden rendelkezésre állt, ami a katonák és családjuk létfenntartásához nélkülözhetetlen volt. A rokkant katonák gyermekei részére iskola, a nők részére textilmanufaktúra létesült, továbbá volt saját pékségük, mészárszékük, templomuk, ispotályuk, gyógyszertáruk és temetőjük is (Mihók, 2018).

\section{Az 1750. évi birodalmi rokkantellátási pátens}

A III. Károly által 1716-ban alapított azonban még unokája II. József uralkodása alatt sem befejezett, és 1783-ban végleg bezárt - intézmény, a Pesti Invalidus Ház a rokkantkérdés „tüneti kezelésére” szolgált. Ugyancsak ebbe a kategóriába sorolható Mária Terézia királynő egyik korai intézkedése, amelynek keretében a hétéves háború rokkantjainak már nemcsak obsitokat osztott, hanem a Bécs melletti „Theresienfelden” 30100 holdas birtokokat is, teljesen egyformán épült lakóházakkal (Melly, 1932). Azonban ezek az intézkedések sem oldhatták meg a mind nagyobb számú hadirokkantak sorsát, amely így egyre inkább összbirodalmi üggyé vált. Ezért sem meglepő, hogy a rokkant katonák ellátásának körültekintő és alapos rendezése Mária Terézia uralkodása idején történt. Ekkor jelent meg ugyanis egy olyan birodalmi rokkantellátási rendelet, amely először nevezte a hadirokkantak ellátását az állam kötelezettségének (Cole, 2014), és amelynek második kiegészítése (1772) még a 19. század végének magyar hadigondozását is meghatározta. A rokkantellátás szabályozásának hátterében elsősorban az egészséges, de elszegényedett, valamint a rokkant katonák között elterjedt utcai kéregetés jogszabályi visszaszorítása állt (Wunder, 1984a).

A rokkantellátási ügyet szabályozó legfelsőbb rendeletnek (2. ábra) egy - Mária Terézia által saját kezúleg aláirt - példányát a Hadtör-ténelmi Levéltár okmányai között találjuk. A tizenkét oldal terjedelmű, 16 pontba szedett és 1750. március 28-án kiadott rendelet címe (Sziij), 2000): „Ordnung, Wie die Invaliden-Soldaten insgemein versorgt 
werden sollen. Wien (gedruckt bey Johann Peter van Ghelen). Ihre Römisch-Kaiserl Königlichen Majestät Hof-Buchdrukkern 1750."

2. ábra: Mária Terézia eredeti aláirásával hitelesitett pátense a rok.kantak ellátásáról (Forrás: HL General Commando 1750-1-100, lásd: Szijj, 2000)

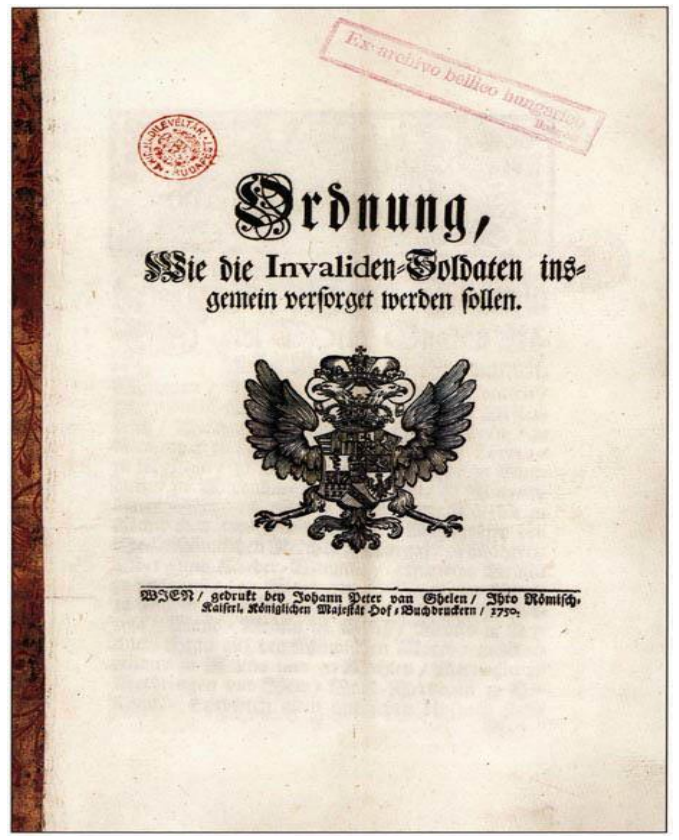

A bevezetésben a rendelet megemlíti, hogy az egyes ezredektől hazájukba visszaküldött harcképtelen, rokkant egyének gyakran nem képesek magukat fenntartani, tehát vagy szükséget szenvednek, vagy a közönség terhére esnek, vagy pedig „szanaszét csavarognak s a közbiztonságot veszélyeztetik”. Azokat a katonákat, akik a tartományok megvédése érdekében egészségüket elvesztették és rokkanttá váltak a tartományoknak kellett ellátniuk és élelmezniük. A császárnő elhatározta, hogy a rokkantak közalapokból kapjanak segélyt, ahogy az Magyarországon szokásos, és ezt a rendszert a többi tartományra is kiterjesztette, vagyis egy úgynevezett „General InvalidenSystem” alapján szabályozta a rokkantellátást (Markó, 1927).

A rendelet befejezett tényként említi, hogy a Pesti Invalidus Házat úgy bővítették ki, hogy abban 2000 közembert és 80, vagy ennél is több tisztet helyeztek el. Az uralkodó intézkedett hasonló rokkantházaknak az örökös tartományokban való felépítéséről is (lásd: Pokorny, 1844), Csehországban 2000 fö részére, Morvaországban 1000 és Ausztriában ugyancsak 1000 fó részére. Prágában, a csehországi hadirokkantház céljára, új épület emelésére adott utasítást, de megjegyezte, hogy „azt a lehető legnagyobb gazdaságossággal és minden fölösleges pompa elkerülésével kell felépíteni”. Morvaországban a hadirokkantházat bérelt épületben akarta elhelyezni addig is, amíg a „Rokkant alap” részére új, megfelelő házat építenek. Az osztrák tartományok részére a bécsi nagy szegényház egy részét jelölték ki rokkantházul. Itt helyezték el a birodalmi rokkantügy központi igazgatását is. Arra az esetre, ha a bécsi rokkantházban „az egyre szaporodó legénység" részére elég hely nem lenne, úgy intézkedett, hogy akik itt nem helyezhetők el, azokat a stájerországi rendek által ingyenesen felajánlott pettaui élelmezési raktárból kialakított rokkantházba kell beutalni.

A pettaui rokkantház 1760-tól a 19 . század végéig működött. A Leobenben, Komotauban és Szakolczán alapított rok- 
kantotthonok azonban már a 19. század elején megszűntek vagy más célra alakították át őket (v.ö.: Szécsi és tsai, 1889, illetve: A Pallas Nagylexikona, 1897, 622. o.).

A Bécsi Rokkantház igazgatása alá került az 1863-ban ,államosított” badeni „Sauerhof' katonai gyógyfürdő továbbá az intézmény 1876-ban a Bécs külvárosában található (neulerchenfeldi) fiókintézménynyel is bővült (lásd: Széczi éstsai, 1889). A Bécsben kialakított rokkantházat 1909-ben lebontották és lakóit egy másik kerületben helyezték el, ahol az intézmény még 1920ig múködött (Net2).

\section{A rokkantházak gazdálkodása és a hadbizottságok felállítása}

Mindazok az alapítványok, amelyek a rokkantak javára létesítettek, megmaradtak az illető rokkantmenház kezelésében. Mária Terézia elhatározta, hogy ezeket az alapokat további források bevonásával növelni fogja. Ezért elrendelte, hogy ha katonai kincstári javakat egyéb célokra más hatóságoknak átadnak, akkor a vagyonátadás után bizonyos százalékot le kell vonni és azt a rokkantalaphoz csatolni. Amennyiben a kincstári javakat külföldre vitték, akkor $10 \%$ ot, belföldön pedig 5 \%-ot. Ezen kívül az uralkodó még a rendelkezésére álló temetkezési alapból is támogatta a rokkantalapot (Markó, 1927). A rokkantak ügyében a királynő alattvalóinak nagylelkűségére is támaszkodott, mert rendeletének befejező részében szinte drámai hangon szól azokhoz az alattvalóihoz: ,,akiket az Isten vagyonnal áldott meg, hogy gondoljanak a rokkantakra, akik oly nagy szolgálatot lettek a hazának és az igényjogosultaknak segítségére legyenek." Mária Terézia a hadirokkantakról végrendeletében is megemlékezett és magánvagyonából minden hadirokkant számára, a rendes ellátáson kívül, egyhavi pénzellátásnak megfelelő összeg kifizetését rendelte el.

Az uralkodó azokban a tartományokban, ahol rokkantmenházat léte-sített, egy katonai és polgári személyekből álló vegyes bizottságot hozott létre, amely bizottság az udvarnál felállított Rokkantügyi Bizottság fennhatósága alá tartozott. A rokkantházak bizottságai minden eseményről jelentést tettek és gondoskodtak arról, hogy a legfelsőbb elhatározásokat és parancsokat mindenki teljesítse.

A rokkant bizottságoknak kötelessége volt az alapítványokat helyesen kezelni, az épületeket kényelmesen, de minden pompa és felesleges hivalkodás nélkül berendezni. Az érdemes rokkantakra különös gondot fordítani, az érdemteleneket az ellátásból kizárni, a betegekről gondoskodni, a létszám növekedését és csökkenését figyelemmel kísérni, gondot fordítani arra, hogy az élelmiszerek, a ruházat és egyéb szükségletek kellő mennyiségben és minőségben beszerzésre kerüljenek. A rokkantak között fegyelem és az Istennek alázatos tisztelete uralkodjon és minden rendben, a törvényeknek és az előírásoknak megfelelően történjék. A rokkantbizottságok (Markó, 1927, 680. o.): „...Mindezzel Istennek dicsőségét növelik, a keresztényi szeretetnek eleget tesznek és megakadályozzák azt, hogy azok az emberek, akik azelőtt hazájukat egészségük és vérük feláldozásával védelmezték, most kénytelenek legyenek, mint keresetképtelenek életüket kóborlással, koldulással tengetni." 


\section{A rokkantházba történő}

\section{felvétel rendje, az igényjogosultak köre}

A rendelet szerint a rokkantházba fel kellett venni (Markó, 1927, 676. o.): „mindenkit, aki a császári-királyi hadseregben szolgálatban állott, vagy áll és sebesülés, vagy egyéb testi fogyatkozás folytán a szolgálat alatt rokkanttá vált és nincsen ellátva”. A rendelet a felvételt a vagyoni helyzethez kötötte a ,vagyonosokat" kizárták a rokkantházból. A rokkantházból továbbá kizárták azokat is, akik a szolgálatból önkéntes lemondás folytán távoztak, vagy mint alkalmatlanokat elbocsátottak, de az alkalmatlanságuk nem a szolgálat folytán, hanem még azt megelőzően keletkezett. Nem kapott az sem rokkantházi ellátást, aki valamilyen más címen kapott kincstári ellátást.

Mária Terézia azonban tökéletesen tisztában volt azzal, hogy a nemzetiség szerinti elosztás nem lehetséges, tehát megengedte, hogy ha a rokkantházakban az egyes nemzetiségek rokkantjait nem lehetne elhelyezni, úgy azok a többi tartományok rokkantházaiban helyezendők el, mivel: „nem a nemzetiség szerinti megosztás és elkülönítés, hanem a jó és olcsó ellátás a fontos". A rokkantházakat és általában az általános rokkantintézményt Mária Terézia tulajdonképen azoknak a hadirokkantaknak alapította, illetőleg egészítette ki, akik mint hadirokkantak az ezredek kötelékéből kiléptek, illetve akik a jövőben végkielégítés nélkül lépnek ki. De kiterjesztették ezt az intézményt azokra a hadirokkantakra is, akik követelésüket (végkielégítésüket) a rendelet hatályba lépése előtt (1750. május 1.) már felvették.

A hadirokkantellátást a rendelet hatályba lépése előtt az egyes országok maguk szabályozták. Ennek több hátránya volt. Az egyik kétségtelenül az volt, hogy az egyes országokban az ellátásra vonatkozólag partikuláris jogszabályok fejlődhettek és fejlődtek is ki. A másik, hogy - mivel nem volt általános központi felügyelet - könnyebben történhettek visszaélések és mulasztások a hadirokkantak kárára. Végül pedig az, hogy az egyes országok - különösen Magyarország nemcsak a véráldozatból vették ki összehasonlíthatatlanul jobban a részüket a közel kilenc évig tartó háborúból, hanem az ennek következményeként felmerülő nagyobb rokkantellátás terheit is magukra kellett vállalniuk. Mária Terézia rendeletének egyik fontos intézkedése volt az, hogy ezeket az egyes országokban lévő rokkantintézményeket kivették az illető országok kezeléséből és ellátásából, azonban azok kötelesek voltak az ezt szolgáló ellátást a közös pénztárba befizetni. Ezáltal lényegében megszabadultak a rokkantellátás adminisztratív terhétől.

\section{A hadirokkantak „osztályba sorolása”}

A hadirokkantakat három csoportba sorolták be:

- az I. csoportba tartoztak azok a hadirokkantak, akik ,teljesen tehetetlenek” voltak,

- a II. csoportba azok, akiket a helyőrségekben könnyebb katonai szolgálatra még alkalmasnak minősítettek,

- végül a III. csoportba azok, akik katonai szolgálat teljesítésére nem, de valamely más foglalkozás elvégzésére alkalmasak voltak.

A pátens 1750-es kihirdetéséhez képest később szigorodtak az egyes kategóriák feltételei, ugyanis a hét éves háború (1756-1763) következtében erősen megnőtt a rokkantak száma (Hölter, 1995). Az I. csoportba 
soroltakat a II. és III. csoportba foglaltak kötelezettségei nem terhelték, azok alól teljes mentességet élveztek. A II. csoport tagjait a helyőrségekben századokba és zászlóaljakba sorolták és ott könnyú katonai szolgálatot láttak el. A III. csoportbelieknek - és a rokkantházban lévő hadirokkantakkal együtt lakó feleségeknek és gyermekeknek - valamilyen foglalkozást kellett űzniük. Ezek részére a rokkantházban múhelyeket rendeztek be, ahol kézműipari cikkeket állíthattak elő.

A rendelet 12. pontja szerint: amennyiben a rokkant ezredétől való eltávozása után nősült meg, akkor magával hozhatta a rokkantházba a feleséget és gyermekeit, ha azokat máshol nem tudta elhelyezni. A család tehát a rokkanttal együtt élhetett mindaddig, amig a rokkant életben volt. A rokkant halála után családja egyszeri kegydíjat kapott, a gyermektelen özvegy 20 forintot, családos özvegy 30 forintot. Ha a rokkant és felesége, tehát mindketten, a rokkantmenházban haltak meg, ellátatlan gyermekeik a menházban maradhatnak és igényük volt napi három krajcár segélyre, fél adag kenyérre és ruházatra mindaddig, amíg őket egy árvaházban, vagy másutt el nem helyezték, vagy pedig képesek voltak saját magukat eltartani (Markó, 1927).

A rendelet szerint olyan termékeket kellett készíteniük, amelyeket a katonaságnál általában használtak és azokat naponta el lehetett adni: például ing, szalmazsákhoz szükséges vászon, pokróc, harisnya, fehérnemú stb. A választott mesterséget azonban nem a nyereség kedvéért folytatták (amit a rendelet határozottan meg is tiltott), hanem azért, hogy: ,ezáltal a káros henyélés elkerültessék és legalább ezeknek a hadirokkantaknak, feleségeiknek és gyermekeiknek alkalom adassék arra, hogy valamit ők is kereshessenek és ezáltal életük könnyebbé váljék." Említést érdemel, hogy az első manufaktúra hazánkban Pesten 1776-ban létesült az Invalidus Házban. Ez az „állami posztó- és pokrócfabrika” a katonaság ellátására és a rokkantak foglalkoztatására szolgált (Nagy, 1975).

\section{A rokkantházi ellátás}

A rendelet szerint a hadirokkantak ellátása pénz- és természetbeni szolgáltatásokból állt. A hadirokkantak pénzellátása a hadseregben viselt rendfokozatuktól és attól függött, hogy melyik ország rokkantházában tartózkodtak. Az alacsonyabb katonai rendfokozatúaknál, az altiszteknél és a legénységi állományúaknál, ha Magyarországon tartózkodtak, általában 25 \%-al volt alacsonyabb a pénzellátás összege, mint az ugyanabban a kategóriában, a birodalom más országaiban tartózkodó rokkantaknál. Ennek az oka kétségtelenül az volt, hogy Magyarországon, mint alapvetően földmûvelő országban, az élelmiszerek ára jóval alacsonyabb volt, mint az iparosodottabb örökös tartományokban. Az a rokkant, aki az egyik országból „átköltözött” a birodalom egy másik országában található rokkantházba, de a pénzellátása magasabb volt az új otthonában folyósítottól: továbbra is jogosult volt a magasabb ellátásra. A rendelet szerint ugyanis a „nagylelkű” uralkodó úgy rendelkezett, hogy: „...nem akarjuk az ilyen intézmények működését a legkisebb mértékben sem megvál- 
toztatni." A pénzellátáson kívül a rokkantaknak járó természetbeni ellátások a következők voltak: kenyér, gyertya, ágy, szállás, fegyver és orvosság biztosítása. Ezeket a természetbeni járandóságokat a rokkantaknak ingyen adták. Abban az esetben, ha a hadirokkant nem tartózkodott a rokkantházban, akkor századokba, vagy zászlóaljakba osztották be, ahol a kenyeret, gyertyát és ágyat a kincstár biztosította, hajlékról pedig az az adott hely gondoskodott, ahová a rokkantat beosztották. Ezekért a szolgáltatásokért a rokkant készpénzjárandóságából semmit sem volt szabad levonni (Szita, 1937). Ha valamelyik rokkant részére külön alapítványt létesítettek, amely ellátási összege nagyobb volt, mint a rendelet szerinti, akkor természetesen ezt a nagyobb ellátást élvezte az illető (Markó, 1927).

Említést érdemel, hogy 1750-ben az uralkodó édesanyja, az özvegy Erzsébet Krisztina királyné „húsz (fő) hosszú szolgálatban megrokkant törzstiszt és tábornok” részére, akik értelemszerűen nem voltak jogosultak rokkantházi ellátásra - egy alapítványt hozott létre. Mária Terézia édesanyja emlékére 1771ben az alapítványi nyugdíjban részesíthetôk számát már 21 főben állapította meg (Sz. Lukács, 1980).

A „testi szükségletek” szabályozásán túl a pátens a rokkantak és hozzátartozóik „lelki gondozásáról” is rendelkezett. Az istentiszteletek végzése, lelki ügyek gondozása és az ifjúság oktatása céljából lelkészek és tanítók voltak a rokkantmenházakba beosztva. Minden rokkantházban működnie kellett egy gyógyszertárnak, orvosnak és sebésznek néhány segéddel. Fegyelem és katonai igazságszolgáltatás tekintetében a rokkant menházak katonai fennhatóság alá gazdálkodásuk és élelmezési cikkek beszerzésére vonatkozó ügyekben a politikai hatóságok alá, kincstári pénzek és alapok tekintetében, továbbá minden létszámukat illető kérdésben, a Hadbiztosság alá tartoztak.

\section{A rokkantházon kívüli ellátások típusai}

A rendeletnek kétségtelenül az volt a célja, hogy a hadirokkantakat a rokkantházban helyezze el, mely a rokkantak általános ellenállásába ütközött, mivel egy kötelező jellegű, örökös elzárásként fogták fel (Wunder, 1984b). Azonban - bizonyos esetekben - az uralkodó engedélyezte, hogy a volt vitézek saját maguk döntsenek, hogy hol szeretnének élni. Mária Terézia rendelete szerint ugyanis (Szita, 1937, 209. o.): „nem az a mi legkegyelmesebb szándékunk, hogy ezeket az intézményes jótéteményeinket (rokkantház) az érdemes hadirokkantak, vagy a többi katonák, mint örökös rabságot meggyűlöljék".

Abban az esetben, ha a rokkantak közül „valamelyiknek kedve és megfelelő testi ereje” volt ahhoz, hogy egy darab földet magáénak mondva megmunkálhasson, akkor ki kellett jelölni a részére - lehetőleg a Temesvári Bánság, vagy Erdély területén - egy ilyen célra fenntartott földet. Ha pedig valamelyik rokkant a rokkantházi elhelyezés helyett inkább szívesebben ment vissza szülőföldjére, akkor, ha kérését megfelelőleg indokolta: haza lehetett bocsátani bizonyos végkielégítéssel.

Amikor egy rokkant valahol az országban földet kapott, akkor ezrede köteles volt neki minden még esedékes illetményét kiszolgáltatni. Ha neki onnan már semmi sem járt, akkor egyfajta „végkielégítésként” („ex cassa invalidorum") 36 forintot kapott, hogy magát felszerelhesse. Ezzel megszűnt a rokkant- 
menházba való ellátási igénye. Ezt a 36 forintot az illető község elöljáróságának jelenlétében kellett a rokkantnak kifizetni, mivel a községnek volt kötelessége az ilyen rokkantat - ha egyszer végkép keresetképtelenné válik - tovább eltartani. Hasonló végkielégítésben részesültek azok az altisztek és közemberek is, akik a rokkantellátásból való elbocsátásukat kérték és végleg hazamenni szándékoztak.

Azok a rokkantak, akik a rendelet hatályba lépése idején még nem kaptak végkielégítést és nem laktak rokkantmenházban, hanem az ország valamelyik községében szülőföldjükön, vagy más helyen tartózkodtak szintén részesültek a rendelet szerint nekik járó pénzbeli ellátásból („ex cassa invalidorum”). Azonban ruházatukról, mindennapi kenyér szükségletükről kötelesek voltak maguk gondoskodni és a községtől, ahol laktak mást nem követelhettek, mint szállást, tüzelőanyagot és világítást. A községeknek kötelességük volt ezeket kiszolgáltatni mindazon érdemek elismeréséül, amelyeket a rokkantak a haza védelmében szereztek. Abból a célból, hogy a rokkantak illetményeiket a rokkantpénztárnál szabályszerűen felvehessék, és azért, hogy a hatóságok „az életükről és tisztességes magaviseletükről” meggyőződést szerezhessenek, a rokkant ellenőrző bizottságoktól egy felírással ellátott pajzsalakú jelvényt kaptak, amelyet kötelesek voltak a mellükön viselni és havonként egyszer az előre kijelölt megyének bizonyos községében megjelenniük.

A pajzsalakú jelvényt már a Francia Királyságban is a rokkant katonák egyértelmű „megjelölésére” használták. Ugyanis a IV. Henrik támogatásával 1576-ban alapított ún. „Maison de la Charité chrétienne" rokkantház lakóinak az uralkodó elrendelte, hogy körgallérjukon egy kékszínű pajzs alakú jelvényt viseljenek, amelyen egy fehér kereszt és a „hű szolgálatért" jelmondat állt. Ez az uralkodói „megbecsülés” látható jele lehetetlenné, illetve kockázatossá tette, hogy a rokkantak az utcán kolduljanak. Lásd: Héjja, 1936.

Itt a kiküldött hivatalnok a rokkantakat megszemlélte, illetményeiket kifizette, az erről szóló jegyzéket pedig a rokkantügyi bizottságnak megküldte. A szemlén a hivatalnok érdeklődött a rokkantak magaviselete felől, és - általában - egyéb ügyeiket is segített elintézni. Figyelmeztette a község elöljáróságát a rokkantakkal szemben fennálló kötelezettségeikre, egyúttal nyomatékosan megtiltotta a rokkantaknak, hogy lakásaikat éjjelenként elhagyják. Amennyiben ezt megtették és bejelentés érkezett, akkor elvesztették a nekik járó élelmet. Ha pedig valamelyik rokkant ellen panasz merül fel, hogy csavarog, a munkát kerüli, vagy botrányt okoz, akkor visszaküldték az illetőt a legközelebbi rokkantházba, ahol a katonai igazságszolgáltatás hatálya alá kerül.

A rokkant tiszteknek jogában állt amennyiben nem volt szükség rájuk, mint felügyelőtisztekre a rokkantmenházakban szabadon választani, hogy a rokkantmenházba kívánnak felvételt nyerni, vagy pedig az ország valamelyik más helységében, községében akarnak véglegesen letelepedni. Ha a rokkantházat 
választották, akkor megkapták összes illetményüket pénzben és természetben is, azon felül pedig a teljes ellátást is.

Abban az esetben, ha valahol máshol kívántak letelepedni, akkor csakis a pénzbeli illetményeiket kapták meg. Amikor egy rokkant tiszt külföldre költözött, elvesztette minden igényjogosultságát, kivéve, ha a kiköltözködésre az uralkodótól előzetesen engedélyt kapott. Hasonlóképpen elvesztették igényeiket mindazok a rokkantak, akik kijelölt helységeikből engedély nélkül végleg eltávoztak, garázdálkodtak, vagy koldultak. Ilyen esetekben a rokkantakat, mint „közönséges csavargó koldusokat" le kellett tartóztatni (Markó, 1927).

\section{A telepítés, mint a rokkantkérdés megoldásának „sikeres” módja}

A rendelet hatályba lépését követően valamennyi megyéhez és városhoz felszólítások érkeztek, hogy alkalmazzanak rokkant katonákat. Ezekben a hivatalos iratokban az szerepelt, hogy tegyenek sürgősen jelentést arról, hogy hajlandók-e erre, van-e üres helyük, továbbá a jelenlegi hajdúik közül pedig az arra alkalmasak nem volnának-e hajlandók inkább katonai szolgálatba lépni és a helyüket a rokkantaknak átengedni. A terv ésszerű volt, azonban mégis számos akadály merült fel. Sok megye és város kellő indokolás mellett írásban kijelentette, hogy nem alkalmazhatja a rokkantakat, mert akik katonai szolgálatra alkalmatlanok, hogyan láthatnák el a pandúrok és hajdúk szolgálatát. „Miként üldözhetnék a tolvajokat - olvashatjuk Bács megye jelentésében - és foghatnák el őket a városban, a faluban, a rablókat a mezőn, az erdőben, miként szállíthatnák be azokat a börtönbe, mikor még ép, erős, egészséges férfiaknak is nehéz megküzdeniök ezekkel a kétségbeesetten védekező emberekkel...”.

A megyék és városok nagy része azonban hajlandó volt könnyebb szolgálatra rokkantakat alkalmazni. Bereg, Borsod, Csongrád, Esztergom, Máramaros, Moson, Nyitra, Sáros, Sopron, Ung, Veszprém és Zala megyék, továbbá Modor, Szakolcza, Szeged, Trencsén, Újbánya és Zólyom már régebben is alkalmaztak rokkant katonákat. Arad megye kijelentette, hogy csak „oláhul tudó” rokkantakat alkalmazhat, Felsőbánya pedig hajlandó volt bányászokként (!) alkalmazni azokat, akiknek volt hozzá kedvük.

A legnagyobb gond azonban az volt, hogy üres hely alig akadt és a már alkalmazásban levők pedig családos emberek lévén, nem voltak hajlandók katonai szolgálatba lépni. Továbbá a megyék sem váltak meg szívesen a már gyakorlott, régi és megbízható embereiktől, így tehát csak arra lehetett számítani, hogy majd a jövőben nagyobb számmal jutnak a rokkantak megyei és városi szolgálatba. A rokkantellátásnak ilyen módon való megoldása tehát nem járt a remélt sikerrel, pedig az egyre égetőbbé vált és a királynő is egyre türelmetlenebbül sürgette a rokkantkérdés mielőbbi, ,végleges” rendezését.

A megoldás kézenfekvőnek tűnt, mivel ekkor már nagyban folytak Erdélyben, a Bánságban és Bácskában a telepítések. Felmerült a terv, hogy ne csak idegeneket telepítsenek be Magyarországra, hanem elsősorban a földművelésre hajlandó és erre még alkalmas rokkantakat is (Pelz, 1916). A királynő azonnal támogatta a tervet és annak kivitelezésével - bizalmasát - Kempelen 
Farkas titkárt bízta meg. Kempelen és Kothmann Antal, aki mint királyi biztos intézte a bácskai telepítéseket, rövidesen kidolgozták a tervezetet, amelyet 1763-ban az uralkodó jóváhagyott („telepítési pátens”) és ennek alapján, már a vállalkozó szellemű családos, de kizárólag katolikus vagy ortodox hitű rokkantak telepítése is elkezdődhetett.

A telepítési politikát következetesen folytató uralkodó fia, II. József már a protestáns felekezetű rokkantak telepítését is engedélyezte. Kevéssé ismert az a tény, hogy II. József halálát (1790. február 20.) követően II. Lipót, I. Ferenc, V. Ferdinánd és a „hivatalnok császár", I. Ferenc József is élt a betelepítés lehetőségével (Gyémánt, 2015).

Kihirdették a rokkant házakban, kaszárnyákban, de az azokon kívül tartózkodó invalidusoknak is tudomására hozták, hogy akik hajlandók földmúveléssel foglalkozni, vagy valamilyen mesterséget folytatni, jelentkezzenek, mert az éppen folyó telepítéseknél a rokkantak előnyben részesülnek. Pozsonyt és Budát jelölték ki gyülekezőhelynek és csakhamar elindultak az első rokkant csoportok a bácsi telepek felé. Az utat hajón tették meg, melyet a Kamara díjtalanul bocsátott rendelkezésükre és ellátásukról is gondoskodott a hosszú út alatt.

Megérkezve „rendeltetési helyükre”, befogadásukra már készen álltak az előre megépített falvak, ahol már volt minden, csak a lakosságnak kellett még „behurczolkodnia”. Ahol az építkezés még nem volt kész ott ideiglenes tömeglakásokban helyezték el a telepeseket. Minden telepes egy teljes jobbágytelket kapott azzal a különbséggel, hogy az iparosok csak falun belüli, „belső telket” (fundus intravillanus) kaptak, és így az ô teljes adómentességük tíz évig tartott. A többiek, akik „külső telket” (fundus extravillanus) kaptak - amely jellemzően szántó vagy rét volt - csak hat évig élvezhették a mentességet. A jelzett idő letelte után évi 3 forint adót fizettek, továbbá 24 robotnapot és más szolgálatokat szabtak ki rájuk.

A házhelyek 900 négyszögölnyi területet foglaltak el a hozzájuk tartozó kerttel együtt. A házat a kamara építette fel és szintén ingyen adta át a telepeseknek, miként a telket is. Egy nagyobb ház felépítése 53 forint 38 krajcárba, egy kisebb házé pedig 33 forint 45 krajcárba került. Ezen kívül kapott minden rokkant telepes a katonai kincstártól 36 forintot a legszükségesebb házi és mezőgazdasági eszközök beszerzésére, továbbá kocsit, ekét, olcsó igavonó- és más házi állatot, vetőmagot és az első évre szükséges élelmet. Az egyes telkek nagyságát 40, egyenként 1600 négyszögölnyi holdban állapították meg, ebből jó termőhelyeken 24, rossz termőhelyeken 32 volt szántóföld (3. és 4. ábra).

\section{3. ábra: A Délvidék betelepitendô új falvait az} osztrák hadmérnökök saketábla alaprajzúra tervezték (forrás: Net3)

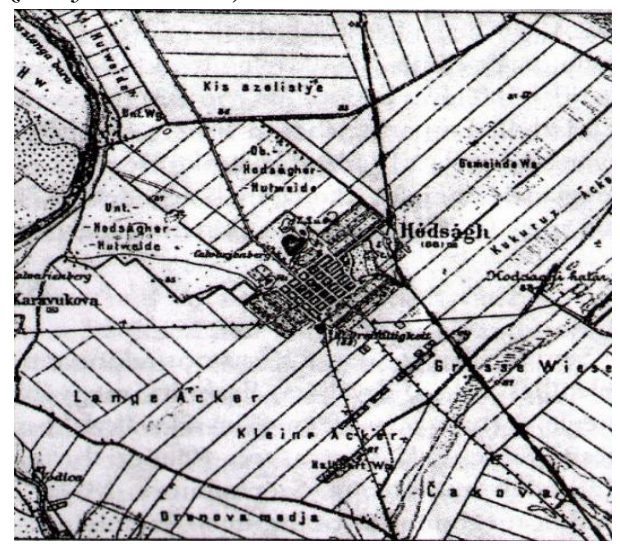


4. ábra: A német telepités ház- és falutipusai (Griselini, 1780)

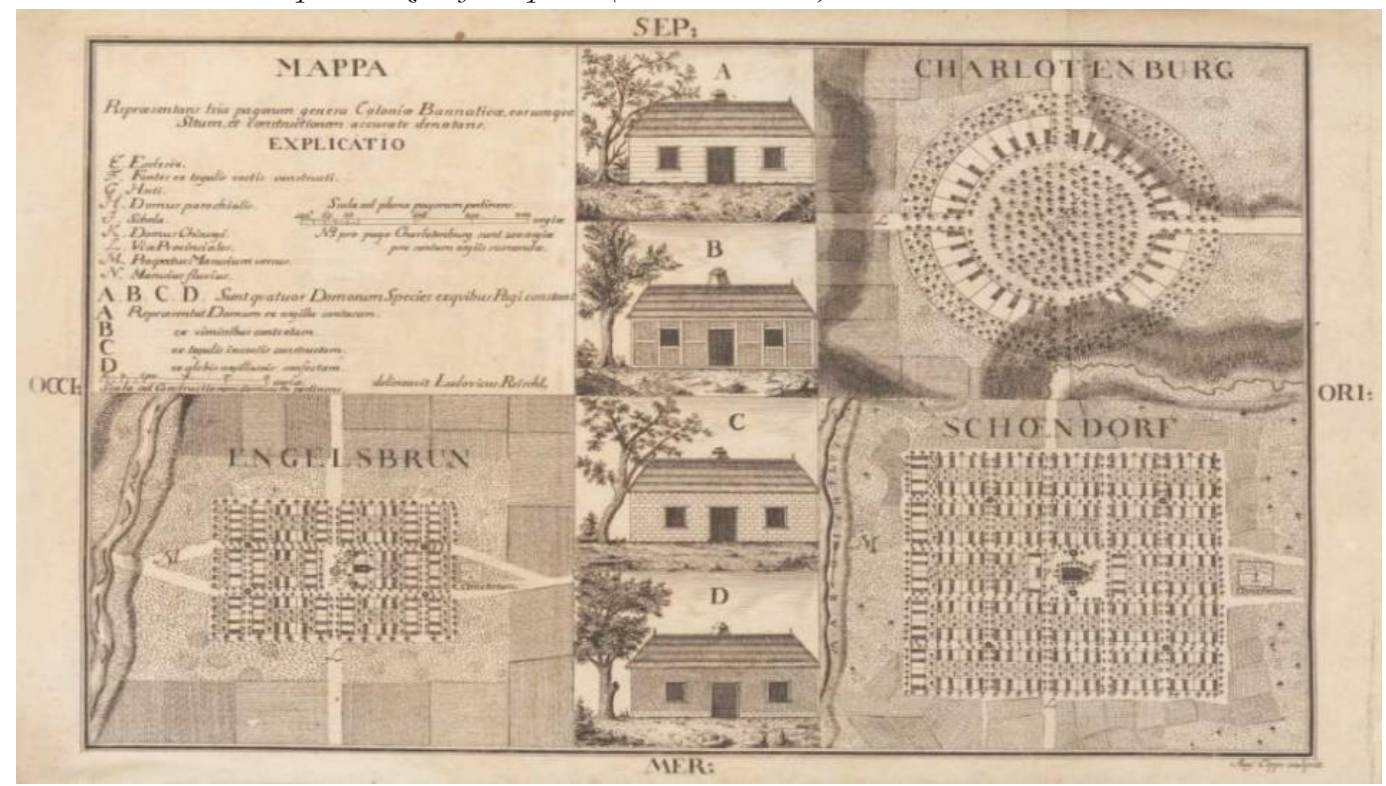

Már az első évben több száz rokkant telepedett le „a kamarai jószágokon” és a következő esztendőkben ez a szám egyre növekedett (Pelz, 1916). Mária Terézia ezért 1766. június 22-én kelt „kegyes resolutiójában” elérkezettnek látta az időt arra, hogy minden faluban pap és tanító legyen és minden két-két falu egy sebészszel is bírjon (Iványi, 1913).

A betelepítés alapvetően birodalmi érdeket szolgált, ezért kivitelezése rendkívül pontos és szervezett volt; ha itt-ott fel is merültek nehézségek, az a telepítés összetett feladatrendszeréből adódott. Az intézkedések folytán a még ellátandó rokkantak száma 20 év alatt kevesebb, mint a felére kb. 8400 före csökkent, akikről azonban továbbra is a Kincstárnak kellett gondoskodnia (v.ö.: Pelz, 1916).

\section{Irodalom}

A Pallas Nagylexikona, Pallas Irodalmi és Nyomdai Rt., Budapest 1897, 6

Cole, L. (2014): Military Culture and Popular Patriotism in Late Imperial Austria. Oxford: Oxford University Press

Gabriel, R. A. (2013): Between Flesh and Steel: A bistory of military medicine from the Middle Ages to the War in Afghanistan. Washington, D.C.: Potomac Books

Gentili, M. (2017): Naissance de l'hôpital moderne. Letöltés: 2020.03.20. Web: https://www. unidivers.fr/breve-histoire-hopital/

Griselini, F. (1780): Versuch einer politischen und natürlichen Geschichte des Temeswarer Banats in Briefen an Standespersonen und Gelehrte, Wien 1780, In. Donauschwäbisches 
Zentralmuseum Ulm. Letöltés: 2020.03.20. Web: https://bawue.museum-digital.de/ index.php? $\mathrm{t}=$ objekt\&oges $=2923 \&$ navlang =hu

Gyémánt R. (2015): A Bánság újratelepítése, különös tekintettel a 18. századi telepítési folyamatokra. Acta Universitatis Szegediensis, forum, Acta Juridica et Politica, (5) 1. pp. 3148. (2015). Letöltés: 2020.03.20. Web: http:/ / acta.bibl.u-szeged.hu/49993/1/ juridpol_forum_005_001_031-048.pdf 44.

Héjja P. (1936): A tábori kórházak Buda ostrománál, Magyar Katonai Szemle, 6. évfolyam 3. negyedév 1936. 190-191.

Hölter, A. (1995): Die Invaliden. Die vergessene Geschicgte der Kriegskrüppel in der europäischen Literatur bis zum 19. Jahrhundert, Stuttgart: Metzler Verlag Stuttgart.

Iványi I. (1913): A Bács vármegyei telepítések áttekintése. A Bács-Bodrog Megyei Történelmi Társulat Évkönyve 29. 1913. 1-2. füzet 32.

Kelényi Gy. (2005): A királyi udvar építkezései Pest-Budán a XVIII. Században. Hatalom és reprezentáció; a hivatalos építészet formaváltozásai. Múvészettörténeti füzetek 28., 19.

Markó Á. (1927): Rokkantellátás Mária Terézia korában. Közgazdasági és Technológiai Közlemények, II. Évfolyam, 9-10. füzet 1927, 675.

Melly J. (1932): A hadigondozottak Budapesten, Budapesti Statisztikai Közlemények 65/1, 25.

Mihók S. (2018): A Pesti Invalidus Ház története. Honvédségi Szemle 2018/5. szám, 128.

Mihók S. (2019): A szegények gondozása („hadigondozás”) az ókori Hellászban és a
Római Birodalomban, Hadtudományi Szemle 12. évfolyam (2019) 3. szám 113-134.

Nagy L. (1975): Budapest Története 1686-1790 Budapest története III. A török kiüretéstöl a márciusi forradalomig. Akadémiai Kiadó, Budapest.

Net1: Invalidusok Háza, Károly kaszárnya. Letöltés: 2020.03.20. Web: http:// egykor.hu/images/2010/ original/budapest-v-keruletinvalidusokhaza-karolykaszarnya-.jpg

Net2: Das „Nepomucenispital” und das Invalidenhaus, Wiener Bezirksmuseum Landstraße. Letöltés: 2020.03.20. Web: http://web.archive.org/web/2014010619 1733/http://www.dasmuseen.net/Wien/ BezMus03/page.asp/2997.htm

Net3: A németek betelepedése. Letöltés: 2020.03.20. Web: https://www.sulinet. hu/oroksegtar/data/magyarorszagi_nemz etisegek/nemetek/mor/a_mori_nemetseg _tortenete_es_elete/pages/004_a_nemete k_betelepedese.htm

Niox, G.-L. (1909): L'Hôtel des Invalides Ch. Delagrave Paris, 1909. 16.

Pelz B. (1916): Rokkantellátás a hétéves háború után, Századok 50. évf. 6. sz. 1916, 373-374.

Pokorny, W. (1844): Die Gebühren des Kaiserl. Königl. Oesterreichischen Heeres an Geld, Naturalien und Service, Witwe \& Sommer, 1844, (In. Bayerische Staatsbibliothek Ludwig str. 1680539 München), 84-85.

Sz. Lukács J. (1980): Mária Terézia korának rendjelei és kitüntetései. A Magyar Numizmatikai Társulat évkönyve. Magyar Numizmatikai Társulat évkönyve, Budapest. 87. 
Szécsi M., Bankalari G., Rieger F. és Danczer A. (szerk.)(1889): A mi hadseregünk, Az Osztrák-Magyar Monarchia népei fegyverben és zászlók alatt. Franklin-Társulat Magyar Irod. Intézet és Könyvnyomda, Budapest.

Szijj J. (sorozatszerkesztő)(2000): A Hadtörténelmi Levéltár Képeskönyve (III. A császári sas ármyékában 22 Bécs, 1750. március 28. Mária Terézia eredeti aláirásával bitelesitett pátense a rokekantak ellátásáról. HL General Commando 1750-1-100) Petit Real Könyvkiadó, Budapest. Letöltés: 2020.03.20. Web: http://mek.oszk.hu/04900/04995/html/ \#d1e716

Szita I. (1937): Hadigondozás Mária Terézia idejében, Magyar Katonai Szemle 7. évfolyam, 4. negyedév 1937. 209-210.

Takáts L. (1975): Hazai forrásadatok a katonakórházak XVII-XVIII. századbeli fejlődéséhez (I. rész), Honvédorvos XXVII. évfolyam 1975. 389-390.
Takáts L. (2007): A Rákóczi-sqabadságharc egészségügye, Készüllt dr. Takáts László orvoseqredes kutatásai, valamint dr. Takáts Endre levéltárossal együtt publikált szakecikekei alapján, A szöveget összeállították a Semmelweis Orvostörténeti Múzeum, Könyvtár és Levéltár, valamint a Magyar Tudománytörténeti Intézet munkatársai, Budapest. Letöltés: 2020.03.20. Web: https://mek.oszk.hu/05400/05419/

Wunder, B. (1984a): Die Institutionalisierung der Invaliden-, Alters- und

Hinterbliebenenversorgung der Staatsbediensteten in Österreich (1748-1790) Mitteilungen des Instituts für Österreichissche Geschichtsforschung, 92, 1984, 343. Wunder, B. (1984b): Die Institutionalisierung der Invaliden-, Alters und Hinterbliebenenversorgung der Staatsbediensteten in Österreich. Institut für Österreichische Geschichtsforschung, Mitteilungen; Innsbruck, 1984, 346. 